\title{
Indústria Cultural e Comunicação de Massa: Considerações sobre Produtos Midiáticos "Tradicionais" e "Conservadores" Brasileiros e as Implicações da Mercantilização da Cultura para o Receptor
}

\author{
João Angelo Soares Lemos ${ }^{1}$
}

Resumo: O artigo analisa os aspectos que permeiam a comunicação de massa e a indústria cultural, tidos como conceitos sinônimos, à medida que sugerem a mercantilização de mensagens simbólicas e produtos culturais. Para tanto, após um breve histórico do surgimento dessas manifestações, associadas ao desenvolvimento da sociedade capitalista, oito produtos, separados em quatro categorias (Jornalismo, Publicidade, Cinema e Produto Editorial) são objetos de exame. Os dados levantados apontam para o potencial da mídia de determinar as relações sociais e, em certa medida, a dimensão psicológica dos receptores, bem como para a necessidade de se aproveitar os meios técnicos de reprodução como formas de manutenção da sabedoria popular.

Palavras-chave: mídia, indústria cultural, comunicação de massa, produtos tradicionais, produtos alternativos

\section{Introdução}

Por mais que a comunicação de massa e a Indústria Cultural sejam conceitos continuamente discutidos na sociedade, com especial interesse das academias de comunicação, até hoje não se chegou a

\footnotetext{
${ }^{1}$ Graduando de Jornalismo da Universidade Positivo, Curitiba, Paraná.
} 
conclusões definitivas sobre as implicações desses fenômenos na vida dos indivíduos e na organização social. A transformação de produtos culturais em mercadorias destrói seu valor singular? Ela danifica a capacidade crítica do receptor? Compromete seu processo de formação? Esses são alguns dos questionamentos que envolvem a Indústria Cultural e que tentarei responder neste estudo.

Inicialmente, o artigo estabelece um panorama histórico da comunicação de massa, desde seus primeiros indícios, com a imprensa de Gutenberg, no século XV, até o surgimento da definição de Indústria Cultural, por Adorno e Horkheimer, em 1947. Aqui, optou-se por utilizar os termos "comunicação de massa" e "indústria cultural" como sinônimos, à medida que ambos sugerem a popularização de formas simbólicas nos moldes industriais.

Embora excessivamente pessimistas, as análises de Adorno e Horkheimer a respeito da reprodutibilidade de obras artísticas, de como elas perdem seu valor estético e conteúdo único para se tornarem objetos de interesse coletivo e destinados à venda, parecem fazer sentido no presente artigo. $\mathrm{O}$ exame de oito produtos culturais, quatro classificados como manifestações autênticas da indústria cultural e quatro como expressões alternativas e questionadoras, divididos em quatro categorias (Jornalismo, Publicidade, Cinema e Produto Editorial) demonstra a forma como o público é, de fato, atraído em uma escala 
consideravelmente maior pelos suportes fabricados de acordo com as estruturas capitalistas de produção.

É evidente que todos os produtos aqui analisados encontram-se, de certa forma, amarrados à lógica da indústria cultural, uma vez que o sistema vigente - o capitalismo - impõe a todos a necessidade do lucro. No entanto, há alguns que tentam subverter essa lógica; por isso, serão classificados categoricamente como não pertencentes à indústria cultural. Além disso, é importante destacar que todos os elementos comunicacionais discutidos aqui são brasileiros, com o objetivo de dar foco ao trabalho de pesquisa, bem como facilitar as comparações.

$\mathrm{O}$ grande apelo popular gerado pela revista, propaganda, filme e livro de conteúdo pobre e que não incita o pensamento crítico, ao lado da pouca (ou menor) atenção dada aos que contemplam mensagens de cunho social e que subvertem, de alguma forma, as convenções da produção comunicacional vigente são consequências de um processo amplo e complexo. Do mesmo modo, as implicações da indústria cultural e/ou comunicação de massa na dinâmica social, como o alcance do território psicológico dos receptores e o comprometimento de seu senso crítico, escapam dos limites da pesquisa em comunicação para se enveredar por outras áreas do conhecimento humano.

O objetivo do artigo não é necessariamente tecer críticas negativas à indústria cultural, como fizeram os autores de $A$ Dialética 
do Esclarecimento na década de 40, mas lançar luz sobre a questão e questionar a influência desse fenômeno na vida dos indivíduos.

\section{Comunicação de massa e Indústria Cultural}

Embora o termo "comunicação de massa" tenha começado a ser discutido com mais interesse somente na contemporaneidade, a origem desse fenômeno data da metade do século $\mathrm{XV}$, quando a máquina impressora de Gutenberg viabilizou a disseminação de conteúdos gráficos por toda a Europa. Por meio de métodos bastante inovadores à época, que incluíam a aplicação de tinta sobre um bloco, constituído por uma página de tipos, e a compressão do papel contra ele, materiais de conteúdo diverso - principalmente religioso - passaram a circular pelos centros urbanos europeus seguindo uma coerência comercial.

Em 1480 já havia tipografias instaladas em mais de cem cidades pela Europa toda e um florescente comércio de livros tinha surgido. [...] Febvre e Martin estimam que até o fim do século XV, pelo menos 35.000 edições tinham sido produzidas, importando em pelo menos 15 a 20 milhões de cópias em circulação. (THOMPSON, 2001, p. 5556)

É verdade que no século XV uma parcela significativa da população era analfabeta, o que sugere um baixo número de pessoas 
que tinham, de fato, acesso ao que era produzido pela imprensa. Isso, no entanto - indo de encontro ao que muitos acreditam, inclusive teóricos da área - não significa que os livros de 1480 não possam ser definidos como comunicação de massa. Afinal, de acordo com John B. Thompson, em A mídia e a modernidade - uma teoria social da mídia, o termo "massa" não deve ser reduzido à ideia de quantidade, mas considerar se os produtos em questão "estão disponíveis em princípio para uma pluralidade de destinatários" (THOMPSON, 2001, p. 30).

Como a religião foi, nesse período, um dos principais conteúdos a serem comercializados por meio dos livros, pode-se dizer que a Bíblia e os textos usados em cultos e orações consistem nos primeiros produtos da comunicação de massa. Ao lado desse tipo de publicação, mas em menor escala, estão os livros de filosofia e teologia clássica e medieval e dos âmbitos jurídico e científico. No século XVI, obras de teor comportamental também passaram a ser consumidas, entre as quais o De Civilitate Morum Puerilium (1530), de Erasmo, que constituía uma espécie de manual prático de boas maneiras para a educação de crianças (THOMPSON, 2001).

$\mathrm{Na}$ época em que surgiram as primeiras máquinas impressoras, a Europa experimentava o rápido crescimento da economia capitalista, característico da transição da Idade Média para a era moderna. Esse novo contexto, marcado pela modernização das cidades e pela valorização do lucro, explica uma das principais características da 
comunicação de massa: a mercantilização das formas simbólicas, ou seja, a transformação dos produtos culturais em mercadorias. Como se sabe, a base do regime capitalista não está simplesmente no predomínio do capital, mas também na existência de relações de poderio - por isso, é possível afirmar que a comunicação de massa está, também, diretamente articulada à noção de poder simbólico. Conforme explica Thompson, inicialmente, a Igreja, que era uma das instituições de maior influência no século XV, "apoiou fortemente o desenvolvimento de novos métodos de reprodução textual" (THOMPSON, 2001, p. 57).

Apesar disso, é evidente que o advento da indústria gráfica também foi o caminho encontrado por aqueles que desejavam subverter a ordem e promover transformações sociais. Principal nome da Reforma Protestante, movimento contrário à atuação da Igreja Católica, Lutero explorou o potencial da recém-nascida comunicação de massa para difundir pela Europa seus ideais revolucionários.

As 95 Teses de Lutero, inicialmente fixadas à porta da igreja agostiniada de Wittenberg, em 31 de outubro de 1517, logo foram traduzidas para as línguas vernáculas, impressas em folhetos e distribuídas por toda e Europa; estima-se que estas teses tenham chegado ao conhecimento de quase toda a Alemanha em questão de quinze dias e de boa parte da Europa em um mês. Os sermões e tratados de Lutero foram publicados em numerosas edições e logo se tornaram enormemente populares. Seu manifesto À Nobreza Cristã da Nação Alemã foi publicado em 18 de agosto de 1520 e vendeu 4.000 
cópias em três semanas; até 1522 já tinham aparecido 13 edições separadas (THOMPSON, 2001, p. 58).

No texto Indústria Cultural e Comunicação de Massa, Anamaria Fadul (1993) afirma que a produção de informações voltada para o consumo começou no século XIX, com os jornais diários. É verdade que esses constituem uma das mais legítimas manifestações da comunicação de massa, mas mais verdadeiro que isso é o fato de que, em um espaço anterior ao advento do jornal diário, situam-se outros elementos inseridos na trama da comunicação mercadológica, como os citados acima, além do próprio jornal - não necessariamente o diário, mas aquele que já obedecia ao critério de periodicidade.

Ao contrário do que diz Fadul, portanto, já no início do século XVII compilações periódicas de notícias a respeito, principalmente, de acontecimentos internacionais circulavam pela Europa exatamente como produtos da comunicação de massa. Segundo Thompson, os relatos jornalísticos da Guerra dos Trinta Anos foram um dos grandes responsáveis por alimentar a então incipiente indústria da notícia. O grande boom dos jornais, no entanto, aconteceu somente da década de 40 do século XVII, quando ocorreu um surto de publicações, que foi retomado no fim desse mesmo século, após a censura estabelecida por Carlos II, entre 1660 (restauração da monarquia) e 1694, ano em que foi abolida a censura à imprensa na Inglaterra. 
Quando se discute comunicação de massa, surge um outro conceito cujas raízes são bem recentes: o de indústria cultural, sintetizado pelos filósofos alemães Theodor W. Adorno e Max Horkheimer em A Dialética do Esclarecimento, de 1947. De acordo com eles, indústria cultural trata-se da integração das diversas manifestações artísticas e culturais à lógica das relações de troca, fazendo-as perder seu valor cultural para ganhar importância de mercado, conforme mandam as estruturas capitalistas de produção. Bárbara Freitag complementa, no texto A teoria crítica: ontem e hoje, essa particularidade da indústria cultural, baseada nas formulações de Adorno e Horkheimer:

Numa sociedade em que todas as relações sociais são mediatizadas pela mercadoria, também a obra de arte, ideias, valores espirituais se transformam em mercadoria, relacionando entre si artistas, pensadores, moralistas através do valor de troca do produto. Este deixa de ter o caráter único, singular, deixa de ser a expressão da genialidade, do sofrimento, da angústia de um produtor (artista, poeta, escritor) para ser um bem de consumo coletivo, destinado, desde o início, à venda, sendo avaliado segundo sua lucratividade ou aceitação de mercado e não pelo seu valor estético, filosófico, literário intrínseco (FREITAG, 2004, p. 72).

A forma extremamente negativa e "apocalíptica", para utilizar um termo empregado pelo escritor Umberco Eco (1964), como Adorno 
e Horkheimer enxergavam a indústria cultural, definindo-a, por exemplo, como a comprovação do fracasso relativo do Iluminismo, pode ser, em parte, justificada pelo contexto social da época em que edificaram suas teses. Como bem lembra Anamaria Fadul, veículos de comunicação de massa, em especial o rádio e a propaganda, foram explorados, nas décadas de 20 e 30, pelos ditadores Adolf Hitler e Benito Mussolini como estratégia de mobilização das massas para seus ideais imperialistas, nacionalistas, extremistas e antidemocráticos. Além disso, a dupla frankfurtiana ${ }^{2}$ revela em A Dialética do Esclarecimento grande pessimismo ao tratar os efeitos causados pela comunicação de massa à cultura norte-americana.

É por conta desse pensamento negativista que Adorno e Horkheimer derrubaram o modelo idealista elaborado por Herbert Mercuse $^{3}$ anos após ele próprio reconhecer a fragilidade de seu enunciado (Caráter afirmativo da cultura - 1937). Análises feitas por Marcuse sobre a indústria cultural supunham que o entrecruzamento dos dois mundos da sociedade burguesa - a civilização (ou seja, a reprodução material por meio do trabalho) e a cultura (universo das ideias, das artes e do sentimento) -, nos moldes socialistas, tornaria prazeroso o cotidiano dos trabalhadores, que realizariam suas tarefas

\footnotetext{
${ }^{2}$ Theodor W. Adorno e Max Horkheimer foram os principais teóricos da Escola de Frankfurt, instituição alemã de pesquisa sociológica, de inclinação esquerdista e bases marxistas, fundada em 1923.

${ }^{3}$ Outro discípulo da Escola de Frankfurt, Herbert Marcuse explorava a dialética de Marx para tecer críticas à sociedade capitalista.
} 
com satisfação e felicidade. Adorno e Horkheimer, é claro, questionaram essa maneira quase ingênua de pensar a indústria cultural.

Mas como a junção do processo material de produção com o processo de produção de bens ideais e culturais não se deu na perspectiva idealizada por Marcuse, a "democratização" dos bens culturais foi uma falsa "democratização". A dissolução da obra de arte não ocorreu porque o sistema de produção de mercadorias havia suprimido e sim porque ela foi transformada em mercadoria (Adorno e Horkheimer), assimilando-a à produção capitalista de bens (FREITAG, 2004, p. 71).

As discussões atuais sobre a indústria cultural apontam igualmente para o conflito entre "apocalípticos" e "integrados", presente no cenário das pesquisas em comunicação 80 anos atrás (quando foi erguida, a Escola de Frankfurt enfrentou muitos críticos). De lá para cá, vários teóricos teceram críticas aos autores de $A$ Dialética do Esclarecimento, debruçando-se com interesse sobre a teoria crítica. $\mathrm{O}$ fato é que os debates que envolvem o fenômeno não se esgotaram ao contrário, tornaram-se ainda mais polarizados, exaltados e, principalmente, necessários no hodierno. 


\section{Indústria Cultural Brasileira}

Os objetos de análise deste artigo estão divididos em quatro categorias: Jornalismo, Publicidade, Cinema e Produto Editorial. Em cada uma delas, confrontam-se dois produtos culturais que tratam de temáticas bastante diversas entre si (ou, ainda, de mesmos assuntos, mas com vieses opostos), sempre de acordo com os princípios que regem seus fabricantes - enquanto um prima pelo lucro, no contexto da comunicação de massa e da indústria cultural, o outro opta pelo questionamento a alguma realidade social e pelo estímulo à consciência crítica.

Assim, na categoria Jornalismo, serão discutidas as abordagens das revistas Veja e Piauí sobre o enfraquecimento financeiro de Eike Batista; em Publicidade, o famoso comercial dos anos 70 do shampoo Colorama e uma recente divulgação da SOS Mata Atlântica; em Cinema, os filmes De pernas pro ar 2 e Uma onda no ar; e, em Produto Editorial, os livros $O$ alquimista, de Paulo Coelho, e Dom Casmurro, de Machado de Assis. A escolha dos objetos de estudo - todos eles brasileiros - levou em consideração o contexto social em que foram produzidos e em que repercutem, a fim de dar sentido e consistência às comparações.

Notar-se-á que a revista, a propaganda, o filme e o livro categorizados como portadores de conteúdo de fácil compreensão e que 
tratam de temas corriqueiros - condição essencial daquilo que se pretende integrar à Indústria Cultural - mobilizam o público em uma escala muito maior do que os formatos que chamarei alternativos e questionadores - embora nem sempre seus próprios produtores assim os definam ${ }^{4}$.

\subsection{Jornalismo}

No dia 9 de outubro de 2013, a revista Veja publicou na seção de Economia uma nota referente ao notável declínio do império de Eike Batista, empresário que, por muito tempo, ocupou o posto de homem mais rico do Brasil, com uma fortuna de quase US\$ 3 bilhões. No texto A OGX, de Eike, a caminho da recuperação judicial, Veja descreve, nos moldes do jornalismo tradicional, a situação de "quase" falência da petroleira OGX, principal componente da fortuna do magnata. Em uma coluna insignificante, se comparada às demais matérias da edição, de 19 centímetros de altura por 5,6 de largura, a jornalista Malu Gaspar explora no texto elementos como concisão, brevidade e simplicidade, comuns em todos aqueles que fazem parte da indústria cultural.

\footnotetext{
${ }^{4}$ Conforme foi exposto na parte introdutória desde artigo, os produtos aqui analisados e classificados como alternativos e questionadores não escapam à lógica da indústria cultural, uma vez que a coerência econômica e social do mundo atual assim o exige. Esses produtos, no entanto, contemplam qualidades que os diferenciam, de alguma maneira, das obras destinadas somente ao consumo e, por isso, vazias de teor crítico.
} 
Conforme o livro Os 10 Mais (2008), Veja é a revista semanal brasileira que mais vende na atualidade, com uma média de 1,1 milhão de exemplares por publicação (na edição de 9 de outubro, a tiragem foi de 1.181.068). Para atingir esse feito, ela desenvolveu as habilidades necessárias a qualquer veículo de comunicação de massa: construir narrativas superficiais, evitando a exibição densa de ideias, bem como possibilitar leituras pragmáticas, dinâmicas, velozes e descontraídas. Mas, de acordo com Rafael Palomino e Renata Marchezan (2012), embora Veja seja declaradamente um produto da indústria cultural, ela não é dirigida à camada "mediana" da sociedade, como se teoriza a respeito da cultura de massa.

Embora o enunciatário de Veja corresponda a um amplo público leitor, ela não se dirige a um leitor "médio". Em primeiro lugar, o modo como Veja se compõe não visa a uma simples "média dos homens". Ela se volta, na verdade, a um arquétipo relativamente bem definido, um estereótipo burguês de "pessoa bem sucedida". Expressões comuns na discussão sobre mass media como "público médio", "homem médio", "média dos gostos" fazem crer que o produto cultural é democrático, fala a todos do mesmo modo, refere-se a uma porção da humanidade comum a todo ser humano. Na verdade, pelo menos em Veja, o "médio" é o que muita gente deseja ser: a pessoa que "vence na vida" dentro no capitalismo. Não se trata, pois, de média alguma, mas de um construtor social com forte acento ideológico (PALOMINO e MARCHEZAN, 2012, p.76). 
De fato, Veja demonstrou sua inclinação ideológica ao ceder um espaço tão restrito a um fato de certa forma constrangedor para os burgueses e que ganhou atenção muito maior da revista Carta Capital, principal veículo de esquerda do Brasil: a queda de Eike Batista foi matéria de capa da edição de 9 de outubro de 2013. Além de contemplar as características básicas da indústria do jornalismo no que se refere à linguagem, portanto, como sugerem Palomino e Marchezan, Veja é uma autêntica manifestação da indústria cultural também por "dar ao leitor o que ele quer: a ilusão de estar no clube do status quo" (2012, p. 78).

$\mathrm{Na}$ contramão do jornalismo de mercado, com elementos convencionais e superficiais, encontra-se a revista Piauí, que, apesar de fazer parte da Editora Abril, a mesma da Veja, explora uma maneira bastante particular de narrar os acontecimentos da sociedade. Para efeito de comparação, o fato que envolve o empresário Eike Batista foi abordado na edição de outubro da Piauí com uma singularidade jamais vista em Veja. O texto de Mariana Filgueiras, A ruína de Eike, tem como enfoque a promessa não cumprida do bilionário de reformar o quase secular Hotel Glória, que já hospedou incontáveis personalidades, para a Copa do Mundo de 2014.

Por meio de uma narrativa literária, que contempla, entre outros elementos, a enumeração de cenas e a descrição detalhada de ambientes, característica intrínseca das reportagens da Piauí, a 
jornalista retoma, com certa dose de ironia, a crise financeira de Eike Batista ao tratar da fracassada tentativa de transformar o Hotel Glória "no primeiro seis estrelas do Brasil", deixando-o pronto para o grande evento de 2014. Além disso, a matéria revela não apenas custos da reforma, mas também a insatisfação dos moradores com a transformação do prédio histórico em um "canteiro de obras em fase de desmanche", em um texto que, ao contrário do da Veja, ocupa uma página inteira. Isso sugere uma contextualização maior do assunto e a desobediência aos padrões jornalísticos de linguagem.

Apesar de ter recebido inúmeros prêmios que comprovam seu jornalismo de excelência, entre os quais o Veículo Impresso do Ano Prêmio Colunistas 2009, Piauí parece não ter tanto apelo popular quanto Veja: a tiragem da publicação de outubro foi de cerca de 55 mil exemplares - média da revista -, 20 vezes menor que a edição de 9 de outubro da Veja. A explicação para isso é o fato de que um grupo menor de pessoas tem capital intelectual suficiente para compreender o conteúdo da Piauí, cujo principal objetivo é a consolidação da marca, por meio de uma cobertura que rompe com o tradicional, e não apenas as vendas do mês.

Entre outras características da Piauí destacam-se o formato incomum (26,5 cm x 34,8 cm), a impressão em papel refinado, de livro, o abuso de imagens humorísticas e de tiras e quadrinhos irônicos, além da escolha de pautas que, geralmente, não são prioridade na grande 
imprensa. Conforme explica Francilene de Oliveira Silva (2009, p.06) a inovação decorre do desejo do cineasta João Moreira Salles, idealizador da revista, em 2006, de criar um produto inédito, "que fugisse aos padrões de boa parte da imprensa: redução de texto, aumento das imagens, culto às celebridades".

\subsection{Publicidade}

Nos anos 70, a televisão veiculou um anúncio que marcaria para sempre a publicidade nacional e a memória dos brasileiros: o do shampoo Colorama, um produto da empresa Bozzano. Nele, a atriz Dóris Monteiro dá continuidade a uma propaganda anterior, na qual já havia conquistado a simpatia do público por conta de uma voz bastante caricata, interpretando um texto que se tornou o slogan do shampoo. A frase, que caiu no gosto do povo e que ainda hoje é muito ouvida é esta: "Ei, ei! Você se lembra da minha voz? Continua a mesma. Mas, os meus cabelos... Quanta diferença!”. Nesse momento, Dóris passa uma das mãos nos cabelos e, logo em seguida, explica a razão da mudança: "É que pra ele existe shampoo Colorama. Colorama torna os cabelos leves, macios, brilhantes...".

Apesar da má atuação da atriz, que reproduzia sem confiança um texto indubitavelmente decorado, a peça de 30 segundos de duração tornou-se célebre, alavancando as vendas do produto à época e 
contribuindo para a consolidação da marca. Prova do imenso apelo popular do comercial e o quanto ele repercutiu na sociedade ao longo dos anos é o número de visualizações do vídeo cadastrado no site Youtube: 409.988, no dia 15 de novembro de 2013 (o vídeo foi publicado em 15 de agosto de 2007).

Parece que a agência contratada pela Bozzano acertou na divulgação do shampoo Colorama, multiplicando suas vendas a um consumidor que, sem saber, consentia com uma mensagem de conteúdo discriminatório. Nos instantes finais do comercial, Dóris diz: "Quando os cabelos são lindos, tudo é lindo numa mulher". A simplificação da graça da mulher a uma questão puramente estética (o aspecto do cabelo) poderia, já na ebulição dos anos 70 , gerar discussões acaloradas sobre o modo como o feminino é retratado na mídia, sobretudo pelas adeptas do movimento feminista. No entanto, como bem explica Susi Berbel Monteiro, ao parafrasear Jung, em A Indústria Cultural e os meios de comunicação de massa amplificando a persona, é natural que aquilo que pertence à Indústria Cultural provoque a redução da humanidade do indivíduo.

Jung (1982, p. 109), em seu livro $O E u$ e o Inconsciente, argumenta que "o homem produzido por um arquétipo converte-se numa figura coletiva, numa espécie de máscara através da qual sua humanidade não pode desenvolver-se, atrofiando-se cada vez mais" (MONTEIRO, 2009, p. 11). 
No caso apresentado, a máscara são os cabelos "macios, leves e brilhantes" da garota-propaganda. Vestindo-a, o público (em sua maioria mulheres) fragmenta seu ser em prol de uma persona supervalorizada e negligencia-se para ser integrado à sociedade, ou seja, para tentar corresponder ao padrão de beleza imposto pelo anúncio e pelo próprio corpo social. Talvez seja essa a explicação para que as mulheres não questionassem a forma como foram retratadas na propaganda, uma vez que "a partir de uma relação aparentemente genuína, como um elo com o inconsciente, a Indústria Cultural concretiza seus objetivos econômicos e de poder" (MONTEIRO, 2009, p. 97-98)

Em 2008, a organização não governamental SOS Mata Atlântica lançou uma campanha, desenvolvida pela agência F/Nazca $S \& S$ que, ao contrário do comercial do shampoo Colorama, vendia uma ideia, e não um produto. A propaganda, que fez parte de um imenso esforço de comunicação, tinha como conceito a frase Você é vizinho da Mata Atlântica. Respeite para ser respeitado, e, em 45 segundos de duração, mostra um homem assistindo à destruição dos móveis de sua própria casa por uma "árvore humana", fazendo alusão à devastação florestal. O vídeo é composto pelas seguintes cenas: um sujeito vestido de árvore toca a campainha de uma residência. $\mathrm{O}$ morador abre a porta e deixa entrar o visitante inusitado. A partir daí, a árvore começa a despencar 
sobre todos os móveis da casa e, depois de deixar um rastro de destruição, sai tranquilamente pela porta.

Mesmo representando um comercial sem fins lucrativos de grande sucesso, conquistando espaço em diversos canais de televisão, entre os quais a Rede Globo, Você é vizinho da Mata Atlântica. Respeite para ser respeitado certamente não repercutiu na sociedade da mesma maneira que a peça do shampoo Colorama. O comercial provavelmente gerou discussões à época em que foi veiculado, mas os efeitos não se estenderam para a atualidade e, muito provavelmente, cairá no esquecimento do público dentro de quatro décadas, exatamente o tempo que se passou após a febre do Colorama. No Youtube, o anúncio da campanha da SOS Mata Atlântica alcançou 1.558 visualizações até o dia 15 de novembro de 2013 - o vídeo foi publicado em 31 de maio de 2008.

Qual seria, afinal, a explicação para que o público seja mobilizado em escala tantas vezes maior pela propaganda de conteúdo irrelevante e, inclusive, discriminatória, em detrimento da que aponta e questiona um problema social? A resposta não está na estrutura nem, tampouco, no mote no anúncio, mas simplesmente na capacidade diversa que cada um deles tem de "criar uma identificação entre o produto e o comprador" (CORDEIRO SILVA, 2011). Ou seja, na propaganda do shampoo Colorama há algo que falta na da SOS Mata 
Atlântica: a associação de uma particularidade do produto à determinada aparência ou personalidade do indivíduo.

\subsection{Cinema}

No dia 28 de janeiro de 2013, o site www.adorocinema.com publicou uma notícia com a seguinte manchete: De Pernas pro Ar 2 ultrapassa a marca de quatro milhões de espectadores e distribuidora confirma terceiro filme, um mês após o filme ter entrado em cartaz nos cinemas brasileiros. Com isso, a trama produzida pela Paris Filmes passou a ocupar a posição de sexta (ou quinta) ${ }^{5}$ produção cinematográfica nacional que mais levou brasileiros às salas de cinema no século XXI.

A história que atraiu a atenção de tantas pessoas gira em torno de Alice, uma empresária famosa (interpretada por Ingrid Guimarães), dona de um sex shop, que, após um surto de estresse, é obrigada pelo marido a passar alguns dias internada em um spa. Lá, Alice desenvolve uma ideia de produto inovador perfeito para seus negócios, a ser lançado em breve no mercado norte-americano. A partir daí, ela convence sua família a passar um período de "férias" nos Estados

\footnotetext{
${ }^{5} \mathrm{Na}$ reportagem, o jornalista João Victor Figueira afirma que, como o número de espectadores ainda não havia sido divulgado com exatidão, não era possível dizer que De Pernas pro Ar 2 ultrapassou o filme Nosso Lar, que, em janeiro de 2013, ocupava a quinta posição no ranking, com 4.060 .000 espectadores.
} 
Unidos, onde consegue manter contato com investidores e, assim, dar continuidade ao seu trabalho.

A repercussão de De Pernas pro Ar 2 atingiu, inclusive, as redes sociais. Em uma página criada para o longa, inúmeros espectadores teceram comentários diversos, em sua maioria elogiosos, à narrativa. No post De pernas pro Ar 2 foi o filme mais assistido da semana pela $3^{a}$ vez consecutiva! Já passamos o número de espectadores do primeiro filme!, publicado em 22 de janeiro, foram registradas 505 curtidas e 119 compartilhamentos, o que sugere mais uma vez o grande apelo popular da criação da Paris Filmes.

Expressivamente menor foi o sucesso conquistado pelo filme Uma onda no ar, dirigido por Helvécio Ratton e posto em cartaz em 2002, reproduzindo uma história real ocorrida em um conjunto de favelas de Belo Horizonte. Na trama, o jovem Jorge (interpretado por Alexandre Moreno), com a ajuda de alguns amigos, cria a Rádio Favela, veículo comunitário que objetivava atender aos anseios dos habitantes do morro, marginalizados e esquecidos pela elite belo-horizontina. Por meio de uma linguagem simples e uma programação adequada àquele público, a Rádio Favela foi banida pela polícia e Jorge foi preso por operar um veículo pirata. Mesmo assim, a emissora foi premiada pela Organização das Nações Unidas (ONU) por constituir uma ferramenta educativa. 
Apesar de trazer à tona uma infinidade de problemas da sociedade brasileira, entre os quais o racismo, a exclusão social e a violência policial, Uma onda no ar não obteve sucesso perante o público, como reconhece o cineasta Eduardo Valente, em um bate-papo com Ruy Gardnier, Gilberto Silva Júnior, Daniel Caetano, Cléber Eduardo e João Mors Cabral ( $O$ cinema brasileiro e o público em 2002). É verdade que o filme obteve alguma certificação enquanto documento de grande valor social, a exemplo dos dez prêmios conquistados na Europa, Estados Unidos e Brasil, mas quase não houve interesse da população em comparação com o De pernas pro ar 2. Afinal, enquanto o ar com as pernas sensuais de Alice atraíram mais de 4 milhões de espectadores em um mês, o ar com as ondas revolucionárias de Jorge sequer teve números divulgados, o que sugere seu pouco sucesso de público.

\subsection{Produto Editorial}

É indiscutível que Paulo Coelho é, hoje, um dos maiores fenômenos da literatura mundial. Sua obra-prima, O Alquimista (1988), ocupa a posição de quinto livro mais vendido no mundo nos últimos 50 anos, de acordo com pesquisa desenvolvida pelo norte-americano Jared Fanning, em 2012. O eixo central da história é a vida do pastor Santiago, que viaja pelo Saara em busca de um tesouro enterrado 
próximo às pirâmides do Egito, conforme avisavam seus sonhos. Nessa jornada, o jovem encontra pelo caminho várias pessoas que lhe ensinam questões elementares da vida, entre as quais o Alquimista, que decifra os sinais que a vida dá por meio, por exemplo, dos sonhos.

As mensagens pretensamente filosóficas presentes no livro, que desenham o caminho da busca pela vida plena, de fato agradaram. Até hoje, o best-seller, vendeu mais de 60 milhões de cópias no mundo, superando publicações como $O$ diário de Anne Frank e $O$ código $D a$ Vinci. Além disso, em outubro de 2008, o livro colocou Paulo Coelho no Guiness Book of Records, por figurar como o mais traduzido no mundo, em 69 idiomas. Perfeitamente inserido na lógica da comunicação de massa, $O$ Alquimista é o tesouro das editoras que o publicaram - afinal, os leitores parecem não se importar com a superficialidade e com as incorreções gramaticais típicas de Paulo Coelho. No texto As pérolas de Paulo Coelho, publicado em 2005, o professor e revisor J. Milton Gonçalves analisa os atentados à língua portuguesa cometidos pelo grande campeão de vendas. O toma por base a edição de número 159 de $O$ Alquimista, feita pela Editora Rocco:

Não há registro, em nossa literatura, de nenhum outro escritor que tenha empregado haver [grifo do autor] no plural, com o sentido de existir. Não se pode atribuir a culpa ao revisor uma vez que esse modelo de concordância aparece mais de dez vezes em todo o livro (GONÇALVES, 2005) 
O erro a que Milton Gonçalves se refere está na página 22, em que Paulo Coelho afirma que "haviam [grifo meu] certas ovelhas, porém, que demoravam um pouco para levantar [grifo meu]". Além do problema com o verbo haver, o revisor destaca outras duas incorreções presentes na expressão "para levantar". Segundo ele, "Demorar, no sentido de tardar, custar, usa-se com a, e não com para" e "Levantar é sinônimo de erguer; levantar-se é que significa pôr-se de pé” (GONÇALVES, 2005). Mesmo assim, O Alquimista integra a lista de livros preferidos de incontáveis brasileiros.

No extremo oposto de $O$ Alquimista, situa-se o clássico Dom Casmurro (1899), do imortal Machado de Assis. Essa é uma das obrasprimas da literatura brasileira, mas nem por isso passou, algum dia, pela cabeceira de grande parte dos leitores do país. Em resumo, o livro trata da relação entre Capitu e Bentinho e das certezas alimentadas por ele de que a esposa o havia traído com Escobar, seu melhor amigo - para Bentinho, até mesmo seu filho com Capitu (Ezequiel) constituía uma comprovação do adultério, uma vez que, para ele, Ezequiel era a imagem de Escobar. Mas, como a história é narrada do ponto de vista de Bentinho, a ocorrência da traição permanece incerta - sobretudo pelo fato de que, ao longo da narrativa, são apresentadas tanto provas quanto contraprovas do fato.

Dom Casmurro foi escrito no período da literatura denominado Realismo, cujas principais características são a crítica social e a 
abordagem cientificista. Por isso, o clássico constitui, como poucos sabem, um documento de conteúdo extremamente questionador. No artigo A crítica machadiana em Dom Casmurro: um estudo da alegoria feminina como crítica ao sistema republicano no final do século XIX, Ana Patrícia Sá Martins analisa as várias críticas sociais presentes na obra, entre as quais as dirigidas aos profissionais da carreira jurídica, ironizados na figura do personagem Cosme, capitalista nato; e à burguesia, por meio de Justina, prima desonesta e dissimulada.

Percebemos, pois, que estes tipos sociais são bem representativos para demonstrar como a sociedade burguesa oitocentista, tão moralista, católica e cheia de princípios, acabava por mostrar suas verdadeiras personalidades nas atitudes cotidianas. Esta era uma das principais críticas que os escritores da escola Realista/Naturalista enfocam as mazelas sociais e humanas. Porém, diferente dos demais, Machado não prende os seus romances às descrições minuciosas e sempre vendo no ser humano somente suas patologias. Ele vai além, mostra as contradições humanas, tenta aproximar-se do mais real possível da sociedade da qual fala (MARTINS, 2009, p. 38).

Além disso, a autora afirma que várias outras alusões ao contexto social da época estão presentes em Dom Casmurro, como a da personagem Capitu, que muda de personalidade de acordo com a transformação do sistema político da Monarquia para República. Embora essa obra compreenda um valor histórico inestimável e 
demonstre a visão controvertida de um escritor que, a despeito de seu talento, sentia-se marginalizado em um país extremamente racista, há uma desproporção entre as pessoas que se sentem estimuladas a ler $O$ Alquimista e as que se interessam por Dom Casmurro. Prova disso é o fato de que, em mais de 100 anos de existência, o texto machadiano não vendeu sequer uma fração do que Paulo Coelho conseguiu com sua obra mais conhecida, mesmo com seu desfecho absurdamente intrigante e motivador (Capitu traiu ou não traiu?), típico dos clássicos - em oposição aos best-sellers.

\section{A problemática da Indústria Cultural}

Feita a análise dos produtos midiáticos que constituem o objeto de estudo deste artigo, cabe agora discutir os elementos que estão por trás dos conceitos de comunicação de massa e indústria cultural, mas que representam pontos fundamentais para a compreensão do tema. Quando se fala da transformação dos produtos culturais em artigos de venda, é comum manter-se, inclusive nos debates acadêmicos, na superficialidade do tradicional duelo entre "apocalípticos" e "integrados", quando, na verdade, o assunto exige reflexões mais criteriosas e aprofundadas que não se limitem ao campo da comunicação, mas caminhem por áreas diversas do conhecimento. 
$\mathrm{O}$ primeiro aspecto a ser considerado quando se trata de comunicação de massa e indústria cultural é de ordem psicológica. Conforme Susi Berbel Monteiro (2009), os produtos contextualizados na era do desenvolvimento tecnológico interferem na psique humana, determinando o comportamento dos cidadãos e a dinâmica social. Ou seja, jornais, filmes, propagandas, livros, revistas etc. apoderam-se do inconsciente do indivíduo, impedindo-o de explorar livremente a imaginação, à medida que se apropriam da racionalidade e do funcionalismo provenientes da valorização do sistema econômico.

Dessa forma, ao consumir o que é imposto pela indústria cultural, o ser torna-se refém do mundo externo (o do consumismo), perdendo a capacidade de pensar de maneira crítica e de dar significância aos elementos que o rodeiam. E, como bem destaca Monteiro, reavivando as considerações de Baudrillard sobre a sociedade do consumo, é justamente esse processo imbecilizante que permite ao indivíduo sentirse parte da sociedade, embora provoque o afastamento dele de seu próprio inconsciente.

Baudrillard (2007) argumenta que o consumo se estabelece como forma de relação social, como base do sistema cultural. Cria uma nova mitologia, baseada nos objetos, que estabelece uma conexão com a lógica social e a lógica do desejo no campo inconsciente da significação. Porém, essa nova mitologia não dá conta de promover a conexão 
necessária com o inconsciente (MONTEIRO, 2009, p. 07).

É nesse sentido que surge a ideia de homogeneização da massa, ou seja, a conversão do consciente e das necessidades individuais em componentes coletivos. Assim, as necessidades dos homens tornam-se basicamente as mesmas, provocando a instauração de padrões comportamentais e de consumo, que repercutem no interesse exagerado por determinados produtos do mercado midiático, a exemplo da revista Veja, da propaganda do shampoo Colorama, do filme De pernas pro ar 2 e do livro $O$ Alquimista.

Essa padronização, associada a outros fenômenos sociais, tende a provocar também a destruição ou deterioração de culturas genuínas, em um processo intensificado na década de 1980, com a aceleração do sistema de globalização. Como aponta Douglas Kellner, citado por Guilherme Carvalho da Rosa, no trabalho A discussão do conceito de identidade nos estudos culturais, as identidades culturais são, de certa forma, desestabilizadas pela cultura da mídia, processo que é intensificado pela "segmentação do mercado em diversas campanhas e apelos publicitários” (KELLNER, 2001 apud ROSA,

Essa realidade, no entanto, era verdadeira já no princípio da comunicação de massa, nos séculos XVI e XVII. Thompson argumenta que, nos países influenciados pelo protestantismo, dialetos regionais perderam, aos poucos, suas bases institucionais, abrindo espaço para 
uma linguagem padronizada e uniforme, que pudesse ser aceita nacionalmente. De acordo com ele, "Lutero mesmo procurou abandonar seu próprio dialeto nativo, aquele da Baixa Saxônia, e modelar uma linguagem que poderia prontamente ser entendida em todas as terras alemãs" (2001, p. 61).

Ora, como se sabe, variedades linguísticas regionais, manifestadas, por exemplo, por meio das tradições orais, constituem uma das mais importantes expressões da cultura popular; cultura essa que a comunicação de massa encarrega-se, diariamente, de contribuir para eliminar. A transformação da teia social em um esquema padronizado é um processo cotidiano e cada vez mais assustador, apontando para a perda total da tradição - embora Thompson (2001) acredite que a midiatização da tradição não provocou sua destruição, mas a veste de novas caraterísticas, dispensando a necessidade de certos rituais e das limitações da interação face a face.

Outra consequência da comunicação de massa e da indústria cultural a ser considerada aqui é o comprometimento do desenvolvimento intelectual dos receptores. Dizer que a mídia tradicional promove a chamada "semi formação", como sugere Adorno, no sentido de desorientar os indivíduos e promover o empobrecimento do exercício mental, talvez seja agir de forma excessivamente frankfurtiana, mas é inquestionável que a indústria cultural debilita, em certa medida, a capacidade contestadora do público. 
Uma das funções da mídia atual, segundo o otimista Thompson (2001), é contribuir para o "processo de auto formação", em virtude, principalmente, de seu caráter acessível e "livre das limitações espaçotemporais da interação face a face". Apesar disso, ela já mostrou também que tem potencial para alienar e dificultar a aquisição de saberes fundamentais. Conforme ficou comprovado até mesmo neste estudo, a obra $O$ Alquimista, por exemplo, que contempla uma série de erros gramaticais grosseiros, é uma representação da má formação proporcionada pela comunicação de massa, embora o conceito de "formação" compreenda inúmeros outros aspectos.

De acordo com Belkis Souza Bandeira (2008), a educação crítica implica a construção de uma formação emancipatória. Isso quer dizer que, se o conceito de indústria cultural vai de encontro a essa observação, as ideologias dominantes estão cada vez mais fortalecidas, uma vez que a lógica da transformação da cultura em mercadoria ganha, a cada dia, sentido maior. A tese de que a indústria cultural contribui para a manutenção do poder instituído é reforçada por Rafael Cordeiro Silva:

Enquanto a arte autônoma critica a ordem estabelecida, os produtos da indústria cultural ratificam-na sem cessar. Se, por um lado, a técnica permitiu a difusão da cultura para amplos setores da população, representando um ganho e colocando em xeque a ideia tradicional de arte e de seus modos de exposição - como pensava Walter Benjamin -, por 176 
outro, sacrificou a lógica intrínseca da arte autônoma, feriu sua autenticidade e pôs a perder sua capacidade de crítica imanente da sociedade (CORDEIRO SILVA, 2011).

A despeito dessas considerações, é preciso reafirmar que os receptores de informação não são indivíduos amorfos que simplesmente reagem de igual maneira aos estímulos da comunicação, como estabelece a Teoria da Agulha Hipodérmica ${ }^{6}$. A padronização de comportamento gerada pela indústria cultural envolve um processo extremamente complexo, identificado como hermenêutico nos estudos de recepção. De acordo com esse processo, "a recepção de um produto da mídia implica um certo grau de atenção e de atividade interpretativa da parte do receptor" (THOMPSON, 2001, p. 44).

Conservadores, capitalistas e integrados diriam que a comunicação de massa é necessária para o progresso da sociedade; afinal, ela possibilitou, graças à reprodução em larga escala, a disseminação de obras acessíveis a um número maior de pessoas, destruindo o conceito de arte como exclusividade das elites, além de ter estimulado, em certa medida, o sentimento de pertencimento social nos cidadãos. Esses argumentos, até certo ponto, são verdadeiros; mas certamente não diminuem a necessidade de se discutir as implicações

\footnotetext{
${ }^{6}$ De acordo com essa linha de pesquisa, conforme aponta Felipe Pena, os receptores são amorfos e isolados, reagindo de igual maneira aos estímulos que recebem diariamente da mídia, especialmente dos conteúdos de apelo emocional.
} 
dos fenômenos da comunicação no contexto atual, conforme tentou-se comprovar neste estudo.

\section{Considerações finais}

É fato que os receptores de conteúdo transmitido pelos mais diversos tipos de mídia não são simplesmente membros passivos do esquema comunicacional organizado por Lassweel em 1948 ${ }^{7}$. Ao contrário, eles reagem de diversas maneiras aos estímulos que recebem cotidianamente da imprensa, da publicidade, do cinema e do mercado editorial, entre outros. Para Thompson (2001), afinal, a construção da identidade de cada cidadão acontece de forma ativa, com base nos materiais simbólicos que lhe são disponíveis.

De uma maneira ou de outra, essas reações estão sempre articuladas às imposições da indústria cultural e da comunicação de massa. Conforme foi atestado neste artigo, o fenômeno - que surgiu de maneira quase tímida com a grande invenção de Gutenberg, viabilizando a reprodução de materiais impressos, e adquiriu contornos surpreendentes ao longo do tempo - desestimula os receptores a

${ }^{7}$ Em Teoria do Jornalismo (2005), Felipe Pena explica que, segundo o modelo de pesquisa elaborado pelo cientista político Harold Lasswell, em 1948, são cinco os elementos que estão envolvidos na transmissão da mensagem midiática: "Quem?"; "Diz o quê?"; "Por meio de que canal?"; “A quem?”; e "Com que efeito?". 
explorar a imaginação, levando-os, cada vez mais, a consumir produtos pobres em conteúdo.

Isso acontece porque os componentes da indústria cultural tendem a ocupar o inconsciente dos indivíduos de tal forma que contribuem para o processo de padronização característico do modelo capitalista. Além disso, a comunicação de massa tem o potencial negativo de proporcionar uma espécie de formação defasada, o que compromete também a postura de independência dos cidadãos. Ou seja, quanto mais envolvidos na lógica da indústria cultural, mais eles são dominados pelos detentores de poder.

Existe, afinal, solução para a problemática da indústria cultural e da comunicação de massa no contexto atual? Levando-se em conta a tendência globalizante e o surgimento contínuo de ferramentas tecnológicas que contribuem para a reprodutibilidade das formas simbólicas, a resposta parece ser um contundente "não". Mas é necessário entender que a coerência social é modificada com o passar do tempo e que tudo deve ser adaptado ao contexto vigente - por isso, as novas tecnologias reprodutoras, ao invés de inimigas, podem ser essenciais para a divulgação de materiais revolucionários, críticos e contestadores e, acima de tudo, para a manutenção da sabedoria popular aos poucos sucumbida pela indústria cultural.

Atualmente, é perceptível - para quem ainda preserva um mínimo de senso crítico - a falta de conteúdos militantes e alternativos 
entre as mensagens transmitidas todos os dias pela mídia. Estes conteúdos poderiam ser responsáveis por enaltecer culturas marginalizadas e movimentos em defesa de minorias. Grande prova de que a sociedade brasileira não se sente plenamente satisfeita com a mídia tradicional foram os protestos de junho de 2013, que ganharam as ruas de todo o Brasil e nos quais os veículos noticiosos foram rechaçados, incluindo agressões a jornalistas que neles trabalham. O povo indígena, a negritude, o feminismo, o orgulho gay, o Movimento Sem Terra (MST), o hip-hop e as subculturas religiosas, bem como o folclore, as identidades sociais e as tradições populares estão cada vez menos representados na mídia. Utilizar o potencial dos meios técnicos de reprodução, portanto, pode ser a chave para o resgate e preservação desses saberes da sociedade e da civilização brasileira.

A criação de veículos comunitários, capazes de sustentar os costumes e hábitos de uma comunidade, ou a elaboração de estratégias amplas de comunicação para a resolução de conflitos e problemas sociais, são algumas alternativas que, embora não representem nenhuma novidade, são fundamentais para a manutenção da diversidade. Os desafios impostos pela lógica da indústria cultural, no contexto do desenvolvimento tecnológico e do sistema capitalista de produção, no entanto, são grandes, tornando essa tarefa objeto de estudos mais complexos, aprofundados e abrangentes. 


\section{Referências}

ALMEIDA SOUZA, Juliana Lopes; LIGÓRIO, Cláudia Alice. Jornalismo literário: o ritual da revista Piauí. Ponta Grossa: Revista Brasileira de Ensino de Jornalismo, 2012, v.1, n.9, p. 143-172.

BANDEIRA, Belkis Souza. Formação cultural, semiformação e indústria cultural: contribuições de Theodor W. Adorno para pensar a educação., Pelotas: Universidade Federal de Pelotas, 2008.

CORDEIRO SILVA, Rafael. Indústria cultural e manutenção do poder. 2011. Disponível em: < http://revistacult.uol.com.br/home/2011/02/industria-cultural-emanutencao-do-poder/>. Último acesso em: 19 de novembro de 2013.

ECO, Umberto. Apocalípticos e Integrados. São Paulo: Perspectiva, 2000.

FADUL, Anamaria. Industria Cultural e Comunicação de Massa. In: FADUL, Anamaria. (Org.). Linguagem e Linguagens. S P: 1993, v._, p. 53-53. 
FREITAG, Bárbara. A teoria crítica: ontem e hoje. S P: Brasiliense, 2004.

GONÇALVES, J. Milton. As pérolas de Paulo Coelho. 2005. Disponível em: http://www.observatoriodaimprensa.com.br/news/view/as_perolas_de_p aulo_coelho>. Último acesso em: 19 de novembro de 2013.

GOUTHIER, Déborah. O Alquimista é o $5^{\circ}$ livro mais vendido no mundo. 2012.

Disponível em http://www.jornalopcao.com.br/posts/ultimas-noticias/o-alquimista-e-o5-livro-mais-vendido-no-mundo>. Último acesso em: 02 de dezembro de 2013.

JUNG, Carl. O Eu e o Inconsciente. In: MONTEIRO, Susi Berbel. A Indústria Cultural e os meios de comunicação de massa amplificando a persona. Sorocaba: Universidade de Sorocaba, 2009.

KELLNER, Douglas, A cultura da mídia. In: ROSA, Guilherme Carvalho da. A discussão do conceito de identidade nos estudos culturais. Rio Grande do Sul: Enciclopédia do Pensamento Comunicacional Latino-Americano, 
LUCAS DA SILVA, Denise. Cinema e favela: representação dos moradores de vilas e favelas no cinema brasileiro da retomada. Belo Horizonte: Centro Universitário de Belo Horizonte, 2006.

MARTINS, Ana Patrícia Sá. A crítica machadiana em Dom Casmurro: um estudo da alegoria feminina como crítica ao sistema republicano no final do século XIX. São Luís: Universidade Federal do Maranhão, 2009.

MONTEIRO, Susi Berbel. A Indústria Cultural e os meios de comunicação de massa amplificando a persona. Sorocaba: Universidade de Sorocaba, 2009.

OLIVEIRA SILVA, Francilene. A revista Piauí na contramão da pós-modernidade. São Bernardo do Campo: Universidade Metodista, 2009.

PALOMINO, Rafael; MARCHEZAN, Renata. O enunciatário da revista Veja: contribuição para discussões sobre indústria cultural e cultura de massa. Araraquara: Gláuks, 2012, v.12, n.1, p. 51-80.

PENA, Felipe. Teoria do Jornalismo. Rio de Janeiro: Editora Contexto, 2005. 
THOMPSON, Jhon. A mídia e a modernidade - uma teoria social da mídia. Petrópolis: Vozes, 2001.

_.O cinema brasileiro e o público em 2002. _ _. Disponível em: <www.contracampo.com.br/48/cinemafalado1.html>. Último acesso em: 16 de novembro de 2013. 